\title{
スマートライフを加速する人体通信技術
}

\author{
越地 福朗*
}

\section{Human Body Communication Technologies Progressing Smart Life}

Fukuro KOSHIJ*

* 東京工芸大学工学部（２43-0297 神奈川県厚木市飯山 1583

* Faculty of Engineering, Tokyo Polytechnic University (1583 Iiyama, Atsugi, Kanagawa 243-0297)

\section{1. はじめに}

近年，ユビキタス社会やスマートライフの実現を目指 し, 人間・社会・環境への安全・安心を実現するセンシン グ技術やデバイス技術, 情報ネットワーク技術などの研究 に注目が集まっている。また, 高密度実装技術や微細加工 技術の進化にともない, 電子機器は小型・軽量化が進み, モバイル（持ち運べる）からウェアラブル（着用できる） へと進化しつつある。2015 年 1 月には, 米国ラスベガスで 開催された International Consumer Electronics Show 2015 (CES 2015)においても, 通信機能やセンシング機能を搭載した スマートグラスやスマートウォッチ, さらには, スマート ソックスなどの新しいタイプのウェアラブル機器などが多 数展示・紹介された ${ }^{1)}$ 。

ユビキタス社会やスマートライフを考えると, 医療機器 やヘルスケア機器でさえ, モバイルやウェアラブル, さら には, インプランタブル（埋め込める）へと進化するであ ろう。

本稿では, 人体周辺に着目したワイヤレスボディエリア ネットワークの一例として, 人体通信をとりあげ, 人体通 信技術の概要とその応用例を紹介する。

\section{2. ワイヤレスボディエリアネットワーク}

図 1 は, 生体内や生体表面から計測可能な生体情報の例 を示したものである。医療・ヘルスケア分野においては, 通信機能を備えた小型センサ端末を生体内や生体周囲に分 散配置し，ワイヤレスボデイエリアネットワークと呼ばれ る通信ネットワークを形成して, ワイヤレスで生体情報の 収集, 解析, 管理を行うことが提案されている2),3)。

ボディエリアネットワークの通信方式としては, 有線通 信, 電波通信, 光通信, 音波通信などがあげられるが, こ こでは, 人体を介して微弱な電気信号を伝送する人体通信 に着目する。

人体通信は, 人体表面または人体周辺に配置されている 電子機器同士を接続するための通信技術であり, 一般的な

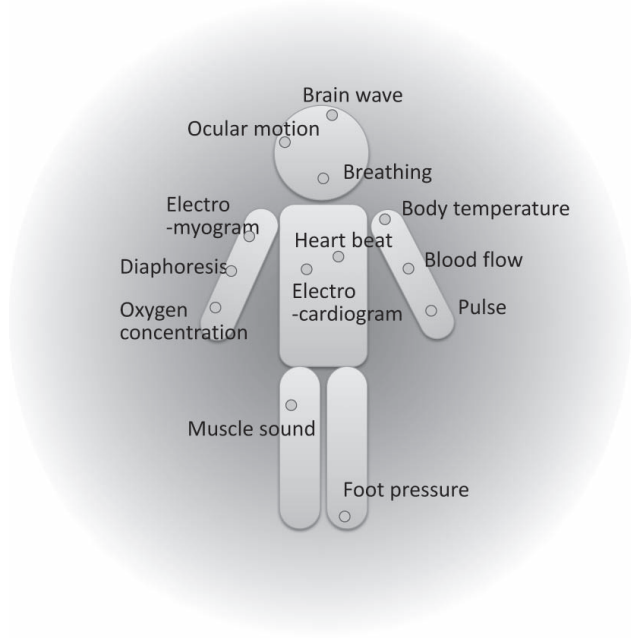

図 1. 生体内や生体表面から計測可能な生体情報

電波通信のように放射電磁界を利用せず，人体自体を電気 信号の伝送媒体として利用するため, 省電力かつ秘匿性に 優れるなどの特長があり，近年，注目を集めている4) 8)。

2012 年 2 月には, 人体周辺における近距離ワイヤレス ネットワークに関する標準規格として，IEEE802.15.6が承 認された ${ }^{9)}$ 。IEEE802.15.6では, 狭帯域ワイヤレス通信と

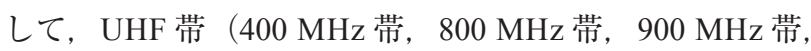
2,360 MHz 带, 2,400 MHz 帯) を, 広帯域ワイヤレス通信 として, Ultra Wideband (UWB) 通信 $(3.1 \mathrm{GHz} \sim 4.8 \mathrm{GHz}$, $6.0 \mathrm{GHz} \sim 10.6 \mathrm{GHz})$ を利用することが規格化され，あわ せて, 人体通信は, Human Body Communication (HBC) とし て，21 MHz 帯を利用する標準規格となっている。また， 本規格には含まれていないが, 産業, 科学, 医療などに利 用可能な国際的な Industry, Science, Medical (ISM) バンドの ひとつである $13.56 \mathrm{MHz}$ を想定し, $10 \mathrm{MHz}$ 付近の周波数 带を利用した人体通信の検討もなされている ${ }^{10)}$ 。

図 2 は, 人体通信の通信形態を示したものであり, 人体 通信用の機器を身につけた一個人内での通信（同図 (a)) や, 握手などによる人体通信用の機器を身につけた複数の人間 同士の通信（同図 $(b))$ ，人体通信用の機器を身につけた人 
間と他の機器との通信（同図 (c)) が想定されている。これ らの通信は, 人体を介して, 他の機器に触れる時に通信が 開始されるため「触れること」を通信のトリガとすること が可能な通信であり, 人間の行動を利用した優れたイン ターフェースとしても注目されている。

人体通信システムの設計を考えると, 電極は, 一般的な ワイヤレス通信システムに打けるアンテナに相当するた め, システムの性能を決める重要なデバイスである。人体 通信におけるウェアラブル機器用電極は, 人体や周囲空間 とのインピーダンス整合を考慮した設計が行われてい る $^{11) ~ 13)}$ 。

また，信号の伝送経路を考えると，大地グラウンドを介 した信号伝送も少なからずあり，人体通信用機器と大地グ ラウンドとの電磁的な結合による伝送特性変動を考慮する 必要がある。人体に装着されるウェアラブル機器は, 小型 であり, バッテリ駆動されるため, ウェアラブル機器と大 地グラウンドとの電磁的な結合は小さい。一方で, 図 2 (c) に示すような据え置き型機器は, ウェアラブル機器に比べ て大型であり, 商用電源のアースとも接続して利用される

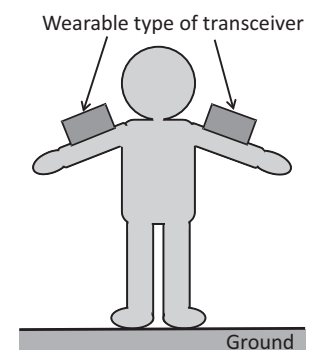

（a）一個人内における通信

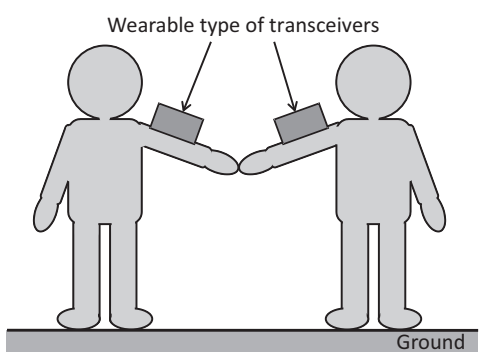

（b）複数の人間同士における通信

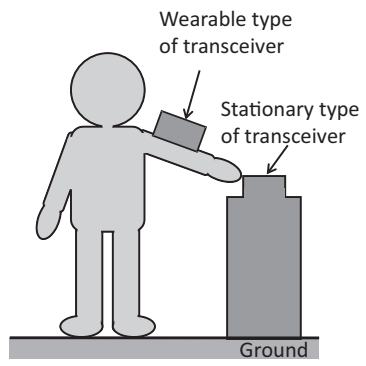

（c）人間と他の機器における通信

図 2.人体通信の通信形態
のが一般的であり，据え置き型機器と大地グラウンドとの 電磁的な結合はウェアラブル機器とのそれに比べて大き い。こうした背景から，大地グラウンドの影響を考慮した 据え置き型人体通信システムに扔ける伝送特性や電磁界分 布などに関する検討も行われている ${ }^{14), 15) 。}$

図 3 は，人体通信の伝送特性を検討する通信システムで あり, 左右の電極に手のひらで触れることにより, 左腕, 胴体，右腕を伝送経路とする電気信号伝送が行われる。

図 4 は, 眓3 のシステムに扔いて, 左右の電極をネット ワークアナライザに接続し，人間が左右の手で電極を握 り，左右の腕部および胴体を伝送経路とした場合の左右の 電極間の伝送特性（実線）を示したものである。また，同 図には比較のために，空間伝搬（手のひらが電極に触れて いない場合）の伝送特性（破線），および空間伝搬と人体通 信との伝送特性の差異（点線）もあわせて示した。被験者 の手は乾燥した状態で実験を行っているが，湿潤状態（汗 で湿っている場合を想定）の検討もあわせて行っており， 両者に大きな差がないことを確認している。また，人体通 信の個人差による特性差異は，体格により最大 $4 \mathrm{~dB}$ 程度の 変動があるが，その周波数特性はほぼ同一であることも確 認している。図 4 に打いては, 29 歳の男性（身長 $165 \mathrm{~cm}$, 体重 $59 \mathrm{~kg}$ ) の被験者のものを代表例として示している ${ }^{16) 。 ~}$ 図 4 に扔いて，人体伝送と空間伝搬の伝送特性を比較す

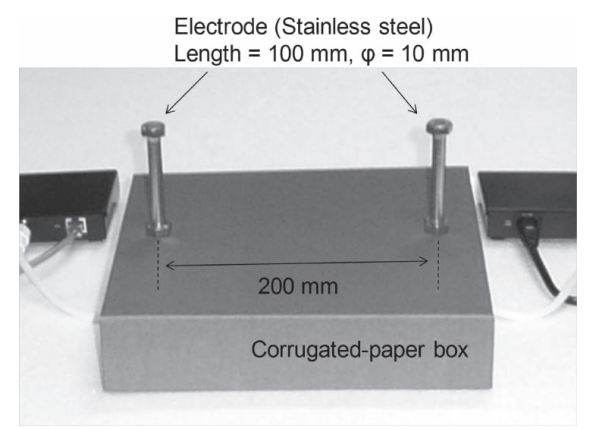

図 3. 人体通信における伝送特性検討システム ${ }^{8)}$

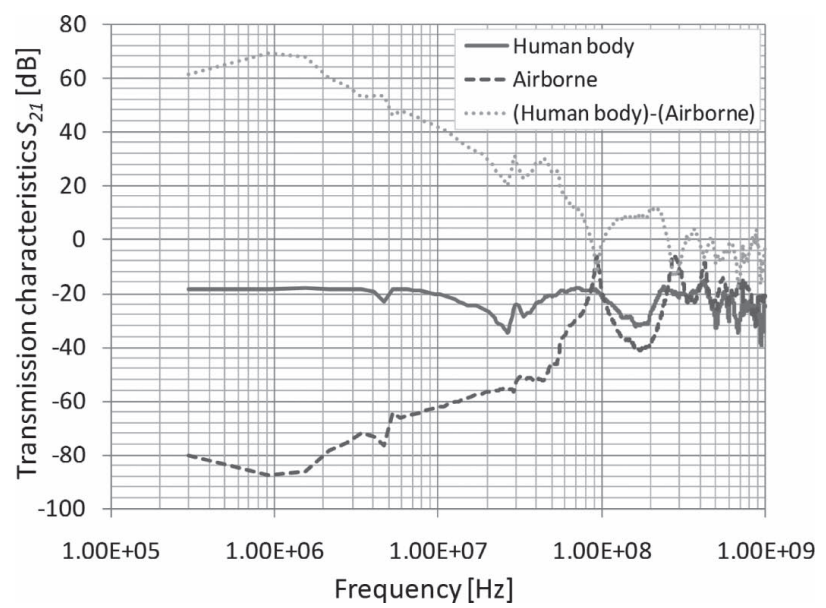

図 4. 人体伝送の周波数特性 
ると, 人体伝送の $S_{2 I}$ 特性は, $30 \mathrm{MHz}$ 以下では, $1 \mathrm{MHz}$ を ピークに人体伝送が $20 \mathrm{~dB}$ 以上良好であり, $80 \mathrm{MHz}$ 以下 では, 人体伝送は $-20 \mathrm{~dB}$ 前後のほぼ一定值を示し, 周波数 に対して安定な通信が可能であることがわかる。一方, 空 間伝搬の $S_{21}$ 特性は, 周波数の増大とともに $20 \mathrm{~dB} / \mathrm{dec}$ で上 昇するが，その值は $-30 \mathrm{~dB}$ 以下であり，人体通信に及ばな w。

図 5 は, 図 3 のシステムにおいて人体が電極を右手のひ らで握っている状態をモデル化し， $30 \mathrm{MHz}$ および $100 \mathrm{MHz}$ の周波数における電界強度分布を電磁界解析した結果であ る。人体モデルは日本人成人男性の平均体型を考慮した寸

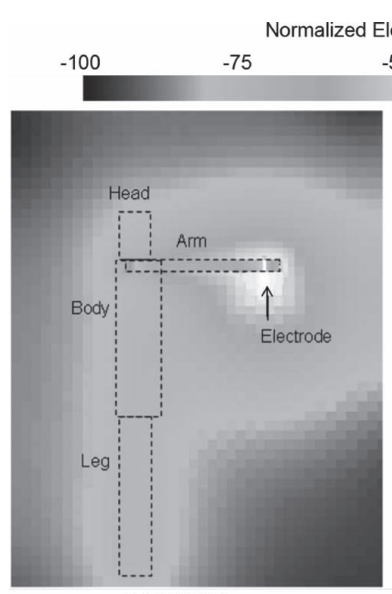

(a) $30 \mathrm{MHz}$
$-25$

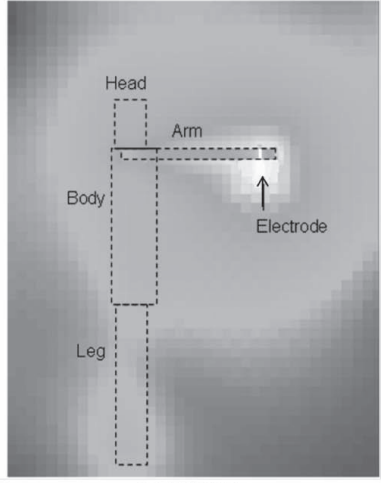

(b) $100 \mathrm{MHz}$
図 5. 電極を握る人体の電界強度分布
法で構成されており ${ }^{16)}$ ，筋肉の電気特性を適用している ${ }^{17)}$ 。

図 5 からわかるとおり, 同図 (a) $30 \mathrm{MHz}$ の電界強度分布 は, 同図 (b) $100 \mathrm{MHz}$ の分布に比べて人体周囲に集中した 電界強度分布を示している。これは低い周波数帯において 人体周囲に集中して電界が分布しており，人体を介した効 果的な伝送が可能であることを意味している。また，同図 (a), (b) ともに前腕部および電極周囲は, 周波数に依存せず ほぼ同様の電界分布となっているが, 解析エリア外周付近 の空間部分に着目すると, 同図 (b) $100 \mathrm{MHz}$ の方が, 同図 (a) $30 \mathrm{MHz}$ よりも強い電界強度分布を示しており, 周波数 が高くなると，人体が電極を握っている場合であっても空 間への放射エネルギが大きいことがわかる。そのため, 図 4 に示すように，低い周波数帯においては人体通信が良好 であり，周波数が高くなるにつれて空間伝搬も良好となる と言える。

\section{3. 人体通信を利用した映像・音声信号の伝送}

人体通信における有力なアプリケーションとして, ウェ アラブルコンピュータとヘッドマウンテッドディスプレイ との間の通信や，音楽プレーヤとヘッドフォンとの間の通 信が想定される。ここではこれらの映像や音声などのマル チメディア情報を伝送するアプリケーションの検討例を紹 介する。

図 6 は，試作した人体通信を利用した映像・音声信号伝 送システムである。図 6 (a)に人体通信を利用した映像・音

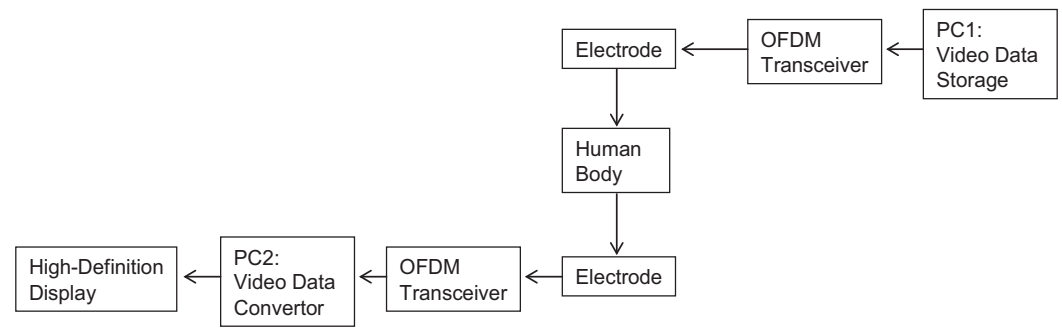

（a）映像・音声信号伝送のための人体通信システムブロック図

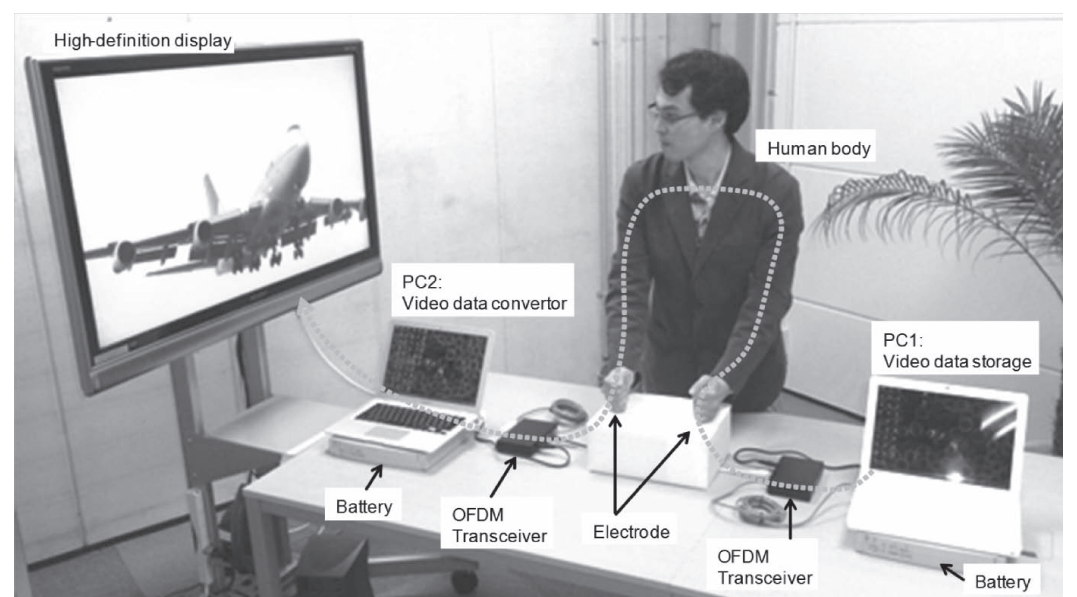

（b）映像・音声信号伝送のための人体通信システム外観

図 6. 映像・音声信号伝送のための OFDM を利用した人体通信システム 
声信号伝送システムのブロック図を示す。眓 (a) からわか ると㧍り, ビデオデータストレージとして利用する PC1 に 保存されたハイディフィニッションビデオデータを, Orthogonal Frequency Division Multiplexing (OFDM) 変調し, 人体を介して伝送した後, 復調し, さらにビデオデータコ ンバータとして利用するPC2において High-Definition Multimedia Interface (HDMI) 対応デー夕に変換し，ハイビ ジョン対応のディスプレイへ表示するシステムである。図 6 (b) は, 人体通信を利用した映像・音声信号伝送システム の外観である。同図中の点線はデー夕転送の経路を示して いる。また，データ転送プロトコルはデー夕転送の信頼性 の高い Transmission Control Protocol (TCP) を利用している。 $55 \mathrm{MHz}$ 以下の周波数带に扮いては, 図 4 に示したよう に, 人体の伝送特性が空間伝搬に対して $20 \mathrm{~dB}$ 以上の安定 した通信が可能であることから，ここでは，2〜28 MHzを 利用する OFDM 変調を採用している。OFDM 変調は, 無線 LAN (802.11a) や地上デジタル放送などに採用されており，

一般にマルチパスなどによる伝送路の周波数特性変動に強 いことが知られている。人体通信においても，人体の周囲 環境や人体の姿勢, 通信機器筐体の大きさや設置方法など の影響を受けて人体抢よび人体周辺を含む伝送系の周波数 特性変動が発生することが報告されている ${ }^{18)}$ 。したがっ て, OFDM 通信は人体通信に拈ける安定通信に有効と言え る。

図 7 は，本システムで採用した OFDM 変調の仕様を示し たものである。図 7 (a) は, OFDM 変調の機能ブロック図 である。サブキャリア数は 917 , サブキャリア変調マッピ ングには, Binary Phase Shift Keying (BPSK) から最大 1024 Quadrature Amplitude Modulation (1024QAM) が用いられ, 伝送路の特性に応じて, 最適な伝送速度が得られるように 自動的に選択される。また, 誤り訂正符号には第 3 世代移 動通信システム（3G 携帯電話）などに多く利用されている ターボ符号, ガードインターバルにはサイクリックプレ フィックスを用いている。図 7 (b) は, 本 OFDM 送受信機 の出力するスペクトラム波形である。図 7 (b) に示すよう に, 2 28 MHz の広带域な信号が出力されていることが確 認できる。ここで，同図の信号出力に着目すると，2〜15 $\mathrm{MHz}$ では $-25 \mathrm{dBm} / 10 \mathrm{kHz}, \quad 15 \sim 28 \mathrm{MHz}$ では $-42 \mathrm{dBm} / 10$ $\mathrm{kHz}$ 程度となっており, 周波数帯域により出力信号レベル が異なる。これは採用した OFDM 変調 IC の仕様によるも のであるが，これら出力信号レベルの違いは本システムの 構築に打いては影響ないと考える。

伝送するハイディフィニッションビデオ，および，オー デイオの仕様をそれぞれ表 1 および表 2 に示す。ハイディ フィニッションビデオデータは, 一般に $17 \mathrm{Mbps}$ 程度とさ れる地上デジタル放送のコンテンツを想定し，ここでは最 大 $20 \mathrm{Mbps}$ の可変ビットレート動画を採用している。

ここで，一般のデー夕通信においては，情報が正確に伝

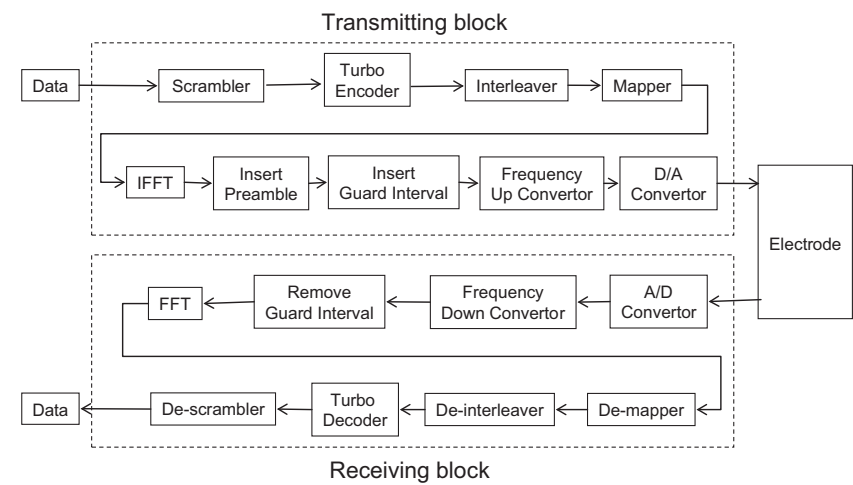

（a）OFDM 送受信機の機能ブロック図

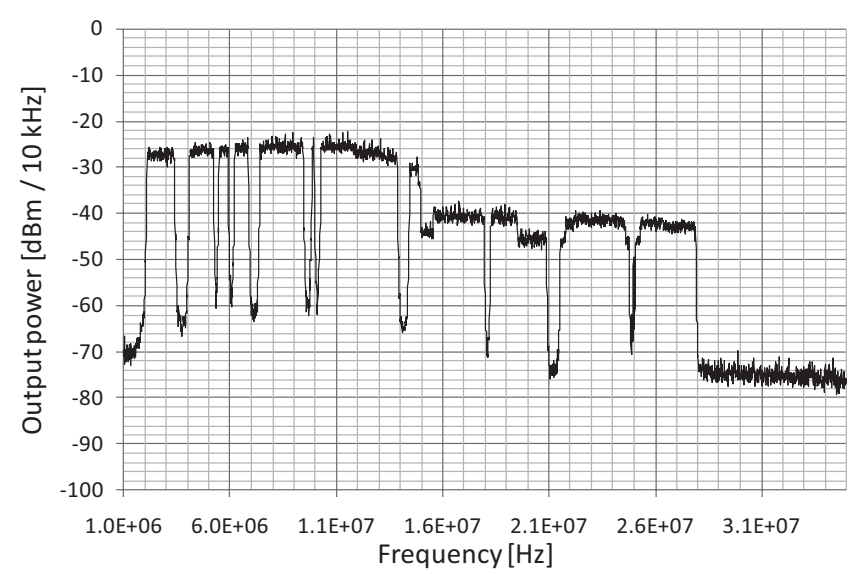

(b) スペクトラムマッピング

\section{図 7. OFDM 送受信機}

表 1. 映像仕様

\begin{tabular}{l|l}
\hline Video pixel size & $1,280 \times 720$ (High-Definition Video) \\
\hline Maximum bit rate & $20[\mathrm{Mbps}]($ Vriable Bit Rate) \\
\hline Frame rate & $30[\mathrm{fps}]$ \\
\hline Run time & $180[\mathrm{~s}]$ \\
\hline
\end{tabular}

表 2. 音声仕様

\begin{tabular}{l|c}
\hline Sampling frequency & $44.1[\mathrm{kHz}]$ \\
\hline Bit rate & $384[\mathrm{kbps}]$ \\
\hline Quantization & $16[\mathrm{bit}]$ \\
\hline Channel & 2 (Stereo) \\
\hline
\end{tabular}

送されること，すなわち，送信デー夕および受信データが 一致することが最重要であるが，映像や音声通信などのマ ルチメディア通信においては，情報が正確に伝送されるこ とだけでなく，情報伝送のリアルタイム性も重要となる。 したがって，デー夕転送遅延なく通信が実現されているこ とを確認する必要がある。

図 8 は, デー夕転送遅延の発生有無を確認するため, 実 際に図 6 (b) に示す構成で，表 1 および表 2 に示す映像・音 声信号を伝送した場合の送信ビットレートと受信ビット レートを示したものである。図 8 からわかるように送信 ビットレートおよび受信ビットレートを比較すると，送受 信ともにデータレートに大きな差異はなく良く一致してお 

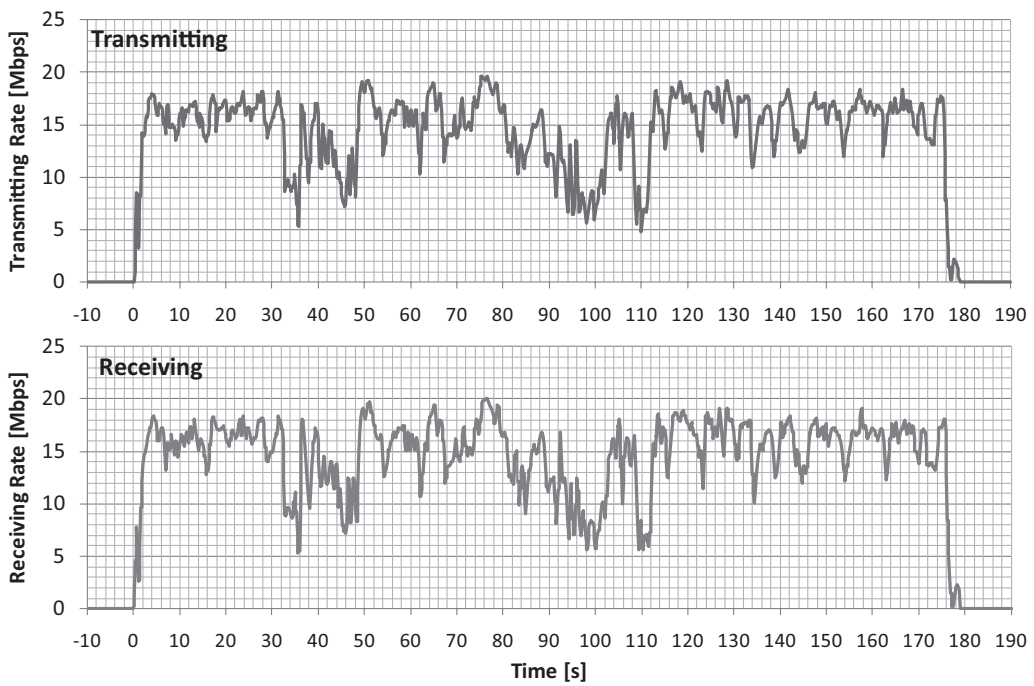

図 8. 送信レートと受信レートの比較

り，デー夕転送遅延なども発生せず安定した映像・音声信 号伝送が行われていることが確認できる。また，あわせ て, 目視による映像デー夕の確認を行い, 映像のコマ落ち などが発生せず，なめらかに映像信号が伝送されることを 確認している。

以上から, 人体通信において, 最大 $20 \mathrm{Mbps}$ の可変ビッ トレートのハイディフィニッションビデオおよびオーディ オの安定通信が可能であることが確認され，人体通信のア プリケーションとして想定されるウェアラブルコンピュー タとヘッドマウンテッドディスプレイとの間の通信や音楽 プレーヤとへッドフォンとの間の通信などのマルチメディ ア映像・音声信号伝送アプリケーションへの応用可能性を 確認することができる。

\section{4. 人体通信技術の自動車システムへの適用}

近年, 安全・安心・快適な交通支援を目的として, 交通 状況を考慮した運転経路提示や衝突防止，車間維持などを 実現する高度道路交通システム (ITS) が実用化されつつあ る ${ }^{19)}$ 。さらに, 運転者の心拍, 体温, 血圧などの生体情報 をウェアラブルセンサでモニタリングすることで，運転者 の状態・状況を把握し, 運転者に提示する運転支援技術に

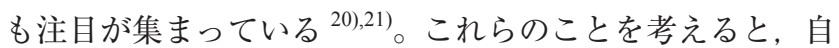
動車内において, ウェアラブルセンサと自動車システムと を接続する通信ネットワークが必要不可欠である。

ここでは，自動車内における安定通信と低消費電力を同 時に実現する通信技術として，人体通信を自動車内に適用 し, 運転者の左右前腕に装着されたウェアラブル機器と, ハンドルに搭載した受信機の間の伝送特性，および周辺の 電界強度分布の検討を行っている。

\section{1 電磁界解析モデル}

図 9 は，運転者の左右前腕に装着されたウェアラブル機 器と，ハンドルに搭載した受信機の間の伝送特性および電

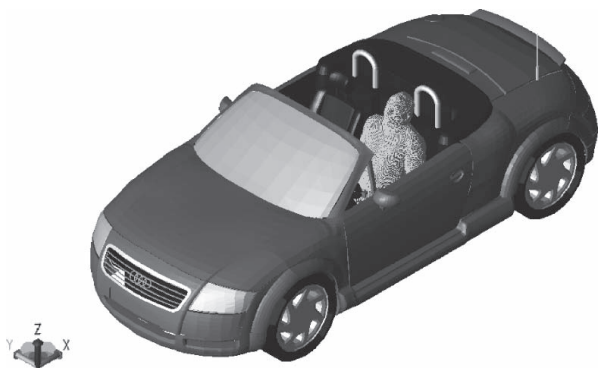

（a）モデル全体図

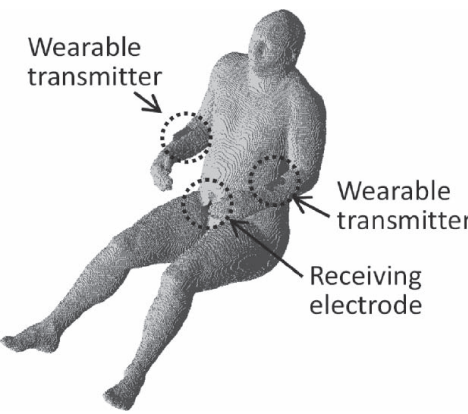

(b) 人体モデル
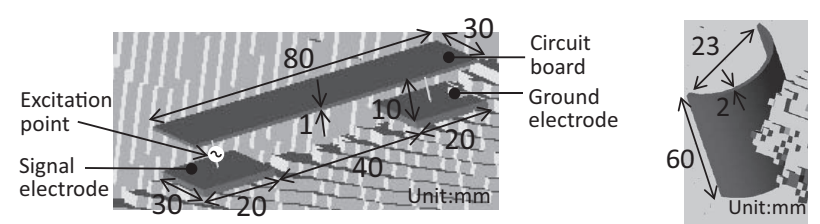

(c) ウェアラブル機器

(d) 受信電極

図 9. 電磁界解析モデル

界強度分布を検討するための電磁界解析モデルである。そ れぞれ，(a) 電磁界解析モデル全体図，(b)人体モデル， (c) ウェアラブル送信機モデル, (d) 受信電極機モデルを示して いる。ここでは一例として, 同図 (a)に示すオープンカー タイプの自動車モデルを利用する。また, 同図 (b) に示す 
人体モデルは, U.S. National Library of Medicine (NLM) より 提供された西洋人男性の平均的な体形を有する全身モデ ル ${ }^{22)}$ を姿勢変形し, 運転席に座りハンドルを握る自動車運 転時の一般的な姿勢としたものである。人体の各生体組織 の電気特性は, 文献 ${ }^{17)}$ に基づいている。

また，同図 (c) に示すとおり，ウェアラブル送信機は, 信号電極, グラウンド電極, 回路基板で構成され, 信号電 極とグラウンド電極の両電極は, 人体表面に接触してい る。信号電極と回路基板の間に $50 \Omega$ の内部インピーダン スを有する励振源が抻入されている。

同図 (d)に，ハンドル表面に配置する受信電極を示す。 受信電極は人体モデルの左手が接触するハンドル部分に配 置されており, 受信電極と金属のハンドルの間には, 受信 機入力抵抗を模擬した $50 \Omega$ の抵抗が挿入されている。

なお，電磁界解析には，Finite Difference Time Domain (FDTD) 法 (XFdtd, Remcom Inc.) を用いている。ここでは, Industry- Science-Medical (ISM) バンドのひとつである 13.56 $\mathrm{MHz}$ の利用を想定し, 周波数 $10 \mathrm{MHz}$ にて検討を行ってい る。

\section{2 伝送特性}

表 3 は, 左右前腕にそれぞれ装着されたウェアラブル送 信機と左手が接触するハンドル表面に配置された受信電極 間の $10 \mathrm{MHz}$ における伝送特性 $S_{21}$ を示したものである。

表 3 からわかるとおり, 左前腕に装着されたウェアラブ ル送信機とハンドル受信電極間の伝送特性は $S_{21}=-31.3 \mathrm{~dB}$ であり，右前腕に装着されたウェアラブル送信機とハンド ル受信電極間の伝送特性は $S_{21}=-62.5 \mathrm{~dB}$ である。受信電 極は，左手が接触するハンドル部分に配置されているた め, 伝送経路が短い左前腕 - 左手ハンドル間の方が良好な 伝送特性を示している。一方, 右前腕一胴体一左手ハンド ル間のように伝送経路が長距離であっても， $-70 \mathrm{~dB}$ 以上の 良好な伝送特性が得られる。この結果は, 過去に報告され た据え置き型機器とウェアラブル機器間の伝送特性 ${ }^{23)}$, す なわち, 図 2 (c) 人体通信用の機器を身につけた人間と他の 機器との通信と類似した結果となっている。このことは, 自動車の車体や据え置き型機器の筐体は, サイズは異なる ものの, ウェアラブル機器や携带機器と比較して大きいた め, 同様の傾向の伝送特性を示すと考えられる。

\section{3 電界強度分布}

図 10 は, 図 9 に示す電磁界解析モデルにおける電界強度 分布を示したものであり, ウェアラブル送信機を装着した 腕部をとおるxy 面における電界強度分布を示している。同 図 (a) は, 左前腕に装着したウェアラブル送信機を励振し た場合, 同図 (b) は, 右前腕装着時に装着したウェアラブ ル送信機を励振した場合の電界強度分布である。図 10 (a), (b)は，どちらも同一の電界強度を基準として表示している。 同図からわかるとおり, 自動車内であっても, ウェアラ ブル送信機近傍から人体周囲にかけて強い電界強度分布と
表 3. ウェアラブル機器と受信電極間の伝送特性

\begin{tabular}{l|c}
\hline \multicolumn{1}{c|}{ Transmission path } & Transmission characteristics $S_{2 l}[\mathrm{~dB}]$ \\
\hline Left forearm - Left hand & -31.3 \\
Right forearm - Left hand & -62.5 \\
\hline
\end{tabular}

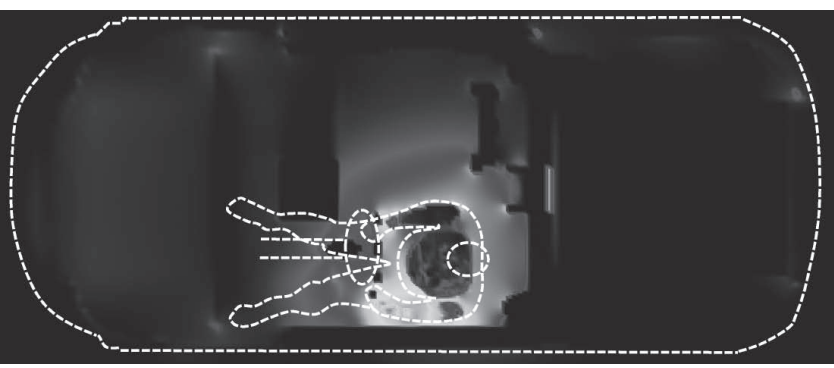

（a）ウェアラブル送信機を左前腕に装着した場合

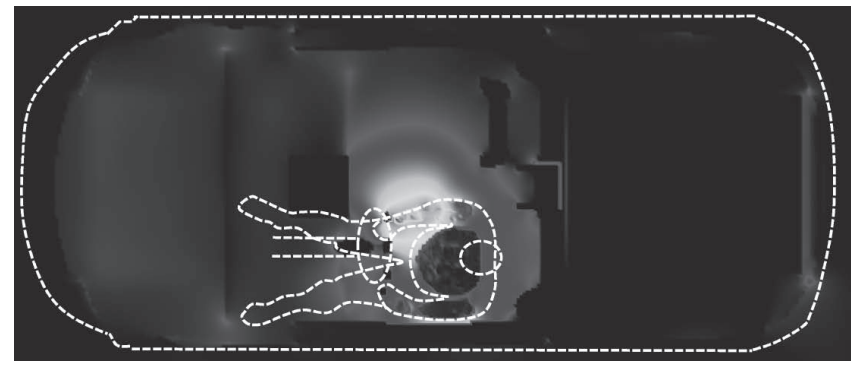

（b）ウェアラブル送信機を右腕に装着した場合

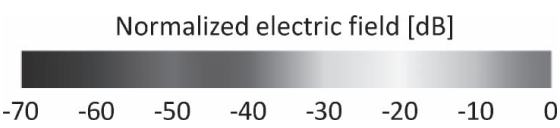

図 10. 電界強度分布

なり，良好な伝送特性を実現できることが確認できる。ま た，人体周囲に電界分布が集中しているが，通信そのもの は微弱な電力によって行われるため, 生体の電磁波の比吸 収率(SAR, Specific Absorption Rate) は小さいと考えられる ${ }^{24)}$

\section{5. まとめ}

本稿では，ユビキタス社会やスマートライフの実現を目 指し，人体周辺に着目したボディエリアネットワークの一 例として，人体通信技術をとりあげ，技術の概要と，人体 通信を利用した映像や音声や，自動車システムへの人体通 信の応用例について紹介した。

\section{謝 辞}

本解説記事で紹介した一部の研究は, 科学研究費補助金 (若手研究 (B)) 課題番号 26750228 によって実施されたも のである。ここに謝意を表する。

(2015.8.2- 受理)

\section{文献}

1) 2015 International CES (http://www.cesweb.org/)

2) 尾崎 徹, 小見正幸, 杉本千佳, 柴 建次, 苗村 潔, 保 坂 寛, 板生 清, 佐々木 健：“ヘルスケア用ウェアラブ 
ルセンシングユニットの開発研究, ”マイクロメカトロニク

ス, Vol. 47, No. 3, pp. 12-19, September 2003

3) H.-B. Li, K. Takizawa, and R. Kohno: "Trends and Standardization of Body Area Network (BAN) for Medical Healthcare," European Conference on Wireless Technology (EuWiT 2008), pp. 1-4, October 2008

4) T. G. Zimmerman: "Personal Area Networks (PAN): Near-Field Intra-Body Communication,” M.S.thesis, MIT Media Laboratory, 1995

5）土井謙之, 西村篤久：“人体を伝送路とする高信頼性通信方 式,”松下電工技報, Vol. 53, No. 3, pp. 72-76, 2005

6) K. Fujii, M. Takahashi, and K. Ito: “Electric Field Distributions of Wearable Devices Using the Human Body as a Transmission Channel," IEEE Transactions on Antennas and Propagation, Vol.

55, No. 7, pp. 2080-2087, 2007

7) K. Sasaki, F. Koshiji, and S. Takenaka: "Intrabody Communication Using Contact Electrodes in Low-Frequency Bands," CRC Press, Taylor and Francis, "Healthcare Sensor Networks - Challenges toward Practical Application", ISBN-13: 978-1439821817, Chaper 3, pp. 51-73, September 2011

8) 井上和弘, 大石崇文, 尾林秀一：“人体通信における受信特 性変化に関するシミュレーション検討,” 2013 年電子情報通 信学会総合大会講演論文集, p. 175, 2013

9) IEEE Computer Society: IEEE Standard for Local and metropolitan area networks Part 15.6: Wireless Body Area Networks, 2012

10) K. Hachisuka, A. Nakata, T. Takeda, Y. Terauchi, K. Shiba, K. Sasaki, H. Hosaka, and K. Itao: "Development and Performance Analysis of an Intra-Body Communication Device," Proceedings of the 12th International Conference on Solid-State Sensors, Actuators, and Microsystems (Transducers 2003), Boston, USA, pp. $1722-1725$, June 2003

11) F. Koshiji and K. Sasaki: "Input Impedance Characteristics of Wearable Transmitters for Body-centric Networks," International Conference on Electronics Packaging 2008 (ICEP 2008), 10B11, pp. 1-6, Tokyo, Japan, June 2008

12) 越地福朗, 佐々木 健: “人体内通信におけるウェアラブル 送信機の電極構造によるインピーダンス整合と電極設計, ” エレクトロニクス実装学会誌, Vol. 12, No. 3, pp. 221-232, May 2009

13) 村松大陸, 山本隆彦, 越地福朗, 越地耕二, 佐々木 健 : “インピーダンス整合を考慮した人体通信送信機の電極設計 と周辺電界に関する検討, ”ライフサポート学会誌, Vol. 24, No. 7, pp. 70-78, 2012

14) F. Koshiji, K. Sasaki, and K. Koshiji: "Input impedance characteristics of fixed type of transceivers in intra-body communication," International Symposium on Antennas and Propagation 2010 (ISAP 2010), 301, pp. 913-916, Macau, November 2010
15) M. Kurosu, F. Koshiji, and K. Koshiji: "Electromagnetic field analysis of Human Body Communication between Wearable and Stationary Devices including the Earth Ground,” International Conference on Electronics Packaging 2014 (ICEP 2014), pp. 744-747, Toyama, Japan, April 2014

16) 生命工学工業技術研究所編：“設計のための人体寸法データ 集, ” 人間生活工学研究センター, 日本出版サービス, ISBN4-88922-093-3 C3040 P4635E, June 1996

17) S. Gabriel, et al.: "The dielectric properties of biological tissues: II. Measurements in the frequency range $10 \mathrm{~Hz}$ to $20 \mathrm{GHz}$," Phys. Med. Biol., Vol. 41, pp. 2251-2269, 1996

18) F. Koshiji, S. Takenaka, and K. Sasaki: “TCP/IP Body Area Network in intra-body transmission using OFDM-based wideband modulation," The Fourth International Conference on Body Area Networks 2009 (BodyNets2009), 2009

19) P. Papadimitratos, A. La Fortelle, K. Evenssen, R. Brignolo, and S. Cosenza: "Vehicular communication systems: Enabling technologies, applications, and future outlook on intelligent transportation,” IEEE Communications Magazine, Vol. 47, Issue 11, pp. 84-95, November 2009

20）三角育生，長谷川将之，佐々木 健，保坂 寛，板生 清， 橋本芳信, 有光知理, 中川 剛, 河内泰司 : “自動車運転者 の疲労センシングのための携帯型評価システムの構築手法 に関する研究,”マイクロメカトロニクス, Vol. 47, No. 2, pp1-10, June 2003

21）中野泰彦，宮川あゆ，佐野 聡：“ドライバの覚醒度検知技 術,” FUJITSU, Vol. 54, No. 4, pp. 416-420, July 2008

22) M. J. Ackerman: “The Visible Human Project," Proceedings of the IEEE, Vol. 86, No. 3, pp. 504-511, Mar 1998

23）越地福朗，黑子美咲，越地耕二：“人体通信を利用したウエ アラブル機器と据え置き型機器との間の通信の検討, ”生活 生命支援医療福祉工学系学会連合大会 2013 (LIFE2013) 論文 集, September 2013

24）村松大陸，越地福朗，越地耕二，佐々木 健：“詳細人体モ デルによる人体通信機器の入力特性および生体暴露に関す る検討, ”生活生命支援医療福祉工学系学会連合大会 2011 (ABML2011) 論文集，O1-1，156，pp. 1-3，Tokyo，Japan， November 2011

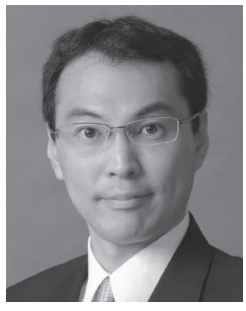

越地福朗（こしぢ ふくろう） 2002 年 東京理科大学理工学部電気工学科卒業。 2002２011 年 コニカ（コニカミノルタに改称） (株) 中央研究所。2010 年 東京大学大学院新領域 創成科学研究科人間環境学専攻博士後期課程修了 (博士 (環境学))。2011～2014 年 国士舘大学理工 学部電子情報学系 専任講師。2015 年 東京工芸大 学工学部基礎教育研究センター 准教授。現在に至 る。また，2010 年より，東京理科大学総合研究機 構客員研究員を併任。電磁波工学, 通信工学, 人 工環境学などの研究に従事。 